\title{
Bicatalytic multistep reactions en route to the one-pot total synthesis of complex molecules: easy access to chromene and 1,2-dihydroquinoline derivatives from simple substrates.
}

\author{
Pascal D. Giorgi, ${ }^{[a]}$ Peter J. Miedziak, ${ }^{[b]}$ Jennifer K. Edwards, ${ }^{[b]}$ Graham J. Hutchings, ${ }^{[b]}$ and Sylvain \\ Antoniotti[a]*
}

\begin{abstract}
By combining nanocatalysis and base-catalysis, a novel one-pot multistep process was found for the synthesis of substituted heterocycles of biological relevance from simple substrates. It is based on an initial $\mathrm{Au} / \mathrm{O}_{2}$ oxidation of allylic alcohols followed by a base-catalysed tandem hetero-Michael/aldolisation/crotonisation with ortho-hydroxy or ortho-amino benzaldehydes. The flexibility of the reaction even allowed the benzaldehyde partner to be prepared in situ in an example of one-pot/5-steps process.
\end{abstract}

After decades of research in organic synthesis methods dominated by the chemical yield as the only metric to evaluate chemical efficiency, new concepts and paradigms have emerged in the 90's introducing atom economy, waste prevention, and safety among others, as mandatory aspects to consider in the development of sustainable chemical processes. ${ }^{[1]}$ Catalysis has thus played a prominent role not only because of the amount of waste prevented when switching from a stoichiometric to a catalytic process, but also because of indirect advantages such as generally lower energy demand (both for temperature and pressure settings), higher degree of selectivity, and new reactions design. In tandem reactions, several chemical steps are achieved in the same pot either upon the sequential introduction of reagents and reactants or upon the use of one or more catalysts operating in both synchronous and asynchronous fashion. The step-economy results in a large amount of waste production avoided, because one or more isolation and purification steps are skipped. These approaches were made possible in modern catalytic methods development either with dual catalysis, cooperative catalysis, bifunctional catalysis, or orthogonal multicatalysis. ${ }^{[2]}$

Multicatalysis has thus attracted an increasing interest recently in a quest for highly selective and efficient synthetic methodologies with a limited impact in terms of waste generation and resource consumption. Examples of combinations of catalysts of the same type have been reported with two organocatalysts, ${ }^{[3]}$ or two or more metal catalysts, for example..$^{[4]}$ More sophisticated cases of orthogonal catalysis were reported by mixing transition metals catalysis with biocatalysis in tandem metathesis/epoxidation reaction, ${ }^{[5]}$ transition metals and organocatalysis with cross-metathesis/iminium/enamine catalysis, ${ }^{[6]}$ organo- and $\mathrm{N}$-heterocyclic carbene catalysis, ${ }^{[7]}$ and more recently photoredox catalysis with organocatalysis ${ }^{[8]}$ and

[a] M. P. D. Giorgi, Dr S. Antoniott

Université Côte d'Azur, CNRS, ICN, Parc Valrose, 06108 Nice cedex 2, FRANCE.

E-mail: sylvain.antoniotti@unice.fr

[b] Dr P. J. Miedziak, Dr. J. K. Edwards, Prof. Dr G. J. Hutchings Cardiff Catalysis Institute, School of Chemistry, Cardiff University, Park Place, Cardiff, CF10 3AT, UNITED KINGDOM. with transition metal catalysis, ${ }^{[9]}$ for example. Conveniently, tandem/domino processes could be triggered the introduction of an electrophilic carbonyl function. Multicatalytic processes based on an oxidation as the first step involved for example a $\mathrm{Cu}$ TEMPO/peptide catalysis, ${ }^{[10]}$ a $\mathrm{Pd}$ NPs-catalysed oxidation/supported amine-catalysed aldolisation, ${ }^{[11]}$ TPAP/NMO-catalysed oxidation/prolinol derivative-catalysed conjugated addition, oxidation/Knoevenagel condensation catalysed by octahedral $\mathrm{MnO}_{2}$ molecular sieve, ${ }^{[12]}$ or oxidation/Biginelli condensation in mechanochemical conditions, ${ }^{[13]}$ for example. Recently, the one-pot synthesis of flavones was proposed catalysed by Au NPs supported on LDH (Layered Double Hydroxide) for which transient alcohols formed upon an aldol reaction were oxidised and further cyclised ${ }^{[14]}$ In different approaches, a whole carbonyl group could be installed for example by hydroformylation of olefins followed an aldol[15] or acyloin ${ }^{[16]}$ reaction, or $\mathrm{Pd}(\mathrm{II})$-catalysed aminochlorocarbonylation/In(III)-catalysed Friedel-Crafts reaction of unsaturated amines. ${ }^{[17]}$ The strategy consisting in the Au NPs $/ \mathrm{O}_{2}$ oxidation of alcohols to generate in situ aldehydes further used as electrophiles has been efficiently used in processes leading to esters, amides, and imines. ${ }^{[18-20]}$ Oxidation of benzyl alcohols to aldehydes under $\mathrm{Au} / \mathrm{O}_{2}$ catalysis is well established, ${ }^{[21]}$ but our strategy required moving towards less studied substrates such as allylic alcohols, which were usually oxidised by more sophisticated nanocatalysts and/or pressurised $\mathrm{O}_{2}$, and simple nanocatalysts. ${ }^{[20]}$ The use of such selective $\mathrm{Au} \mathrm{NPs} / \mathrm{O}_{2}$ oxidative system was envisioned as the best choice to avoid undesired oxidation reactions that should further occur on advanced intermediates or on the final product during tandem processes.

The development of multicatalytic reactions has for prerequisite a good understanding of the individual reactions of concern as well as of their operating conditions (temperature, solvents, rate, conversion, yield, substrates scope). We thus initially focused on the oxidation of benzyl alcohol 1a as a model substrate, as it is considered a benchmark for oxidation by nanoparticles in the literature. ${ }^{[18,22,23]}$ Selected results of the preliminary screening of the reaction conditions and catalysts are summarised in Table 1 (additional data could be found in $\mathrm{SI}$ ). The use of small amounts of $\mathrm{H}_{2} \mathrm{O}_{2}$ or TBHP (5 mol\%) as initiators was beneficial to the oxidation. ${ }^{[24]}$ The best results were obtained with small gold nanoparticles ( $\mathrm{Au} \mathrm{NPs}$, size below $3 \mathrm{~nm}$ ) supported on $\mathrm{TiO}_{2}$, commercially available under the trade name AUROlite ${ }^{\circledR}$. In particular, these small supported NPs were much more active than Au NPs prepared by impregnation (entries 3,6,7). This is likely to be due to the fact that impregnation method often results in bimodal distribution with small $(<10 \mathrm{~nm})$ and large (40$70 \mathrm{~nm})$ NPs. ${ }^{[25]}$ The latter are catalytically inert in our conditions while accounting for a large fraction of the gold content. Reactions in toluene and THF allowed the best results in terms of conversion and selectivity in favour of the formation of 
benzaldehyde $\mathbf{1 b}$, which was the sole product in our optimised conditions (entry 6). Control experiments were performed to rule out possibilities of hidden homogeneous catalysis by leaching of gold species (entry 8 ) and thermal reactions (entry 9). We also found that small amounts of $\mathbf{1 b}$ (less than 1\%) could be formed by oxidation of toluene used as the solvent (entry 10), but one has to consider that toluene could also be formed at the surface of Au NPs by reduction of benzyl alcohol 1a.

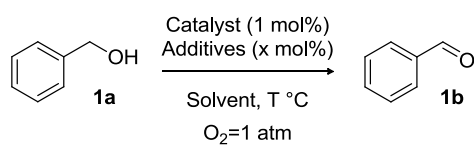

Table 1. Catalysts screening for the oxidation of benzyl alcohol 1a.

\begin{tabular}{|c|c|c|c|c|}
\hline Entry & Cat. $^{a}$ & $\begin{array}{l}\text { Additives } \\
\text { (x mol\%) }\end{array}$ & $\begin{array}{l}\text { Solvent, } \\
\mathrm{T}^{\circ} \mathrm{C} \text {, Time }(\mathrm{h})\end{array}$ & $\begin{array}{l}\text { Conv } \\
{[\%]^{\text {b }}}\end{array}$ \\
\hline 1 & AuPd NPs $/ \mathrm{TiO}_{2}{ }^{\mathrm{c}}$ & - & THF, 65, 16 & 0 \\
\hline 2 & $\mathrm{Au} \mathrm{NPs} / \mathrm{TiO}_{2}{ }^{\mathrm{c}}$ & - & THF, 65, 16 & 2 \\
\hline 3 & $\mathrm{Au} \mathrm{NPs} / \mathrm{TiO}_{2}{ }^{\mathrm{c}}$ & $\begin{array}{c}\text { TBHP } \\
\text { (5 mol\%) }\end{array}$ & Toluene, 90, 6 & 3 \\
\hline 4 & AuPd NPs $/ \mathrm{TiO}_{2}{ }^{\mathrm{c}}$ & $\begin{array}{c}\text { TBHP } \\
(5 \mathrm{~mol} \%)\end{array}$ & Toluene, 90, 6 & 4 \\
\hline 5 & $\mathrm{Au} \mathrm{NPs} / \mathrm{Mg}(\mathrm{OH})_{2}{ }^{\mathrm{c}}$ & $\begin{array}{c}\text { TBHP } \\
\text { (5 mol\%) }\end{array}$ & Toluene, 90, 6 & 12 \\
\hline 6 & $\mathrm{AU} \mathrm{NPs} / \mathrm{TiO}_{2}{ }^{\mathrm{d}}$ & $\begin{array}{c}\text { TBHP } \\
\text { (5 mol\%) }\end{array}$ & THF, 65, 16 & 78 \\
\hline 7 & $\mathrm{AU} \mathrm{NPs} / \mathrm{TiO}_{2}{ }^{\mathrm{d}}$ & $\begin{array}{c}\text { TBHP } \\
(5 \mathrm{~mol} \%)\end{array}$ & Toluene, 90, 16 & 51 \\
\hline 8 & $\mathrm{AuCl}_{3}$ & $\begin{array}{c}\text { TBHP } \\
(5 \mathrm{~mol} \%)\end{array}$ & Toluene, 90, 5 & 0 \\
\hline 9 & - & $\begin{array}{c}\text { TBHP } \\
\text { (5 mol\%) }\end{array}$ & Toluene, 90, 16 & 14 \\
\hline $10^{e}$ & - & - & Toluene, 90,16 & N.A. \\
\hline
\end{tabular}

a $\mathrm{AuPd} / \mathrm{TiO}_{2}: 5 \% \mathrm{w} / \mathrm{w} . \mathrm{Au} / \mathrm{TiO}_{2}: 5 \% \mathrm{w} / \mathrm{w}, 1.94 \mathrm{~nm} . \mathrm{Au} / \mathrm{Mg}(\mathrm{OH})_{2}: 1 \% \mathrm{w} / \mathrm{w}$. $\mathrm{Au} / \mathrm{TiO}_{2}$ (AUROlite): $1 \% \mathrm{w} / \mathrm{w}, 1.56 \mathrm{~nm}$. Used in $1 \mathrm{~mol} \%$ catalyst/substrate

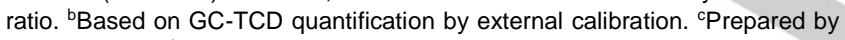
impregnation. ${ }^{d}$ Commercially available under the trade name AUROlite.

Reaction performed in the absence of substrate $\mathbf{1 a}$. Traces of $\mathbf{1 b}$ were observed (less than 1\%), formed upon oxidation of toluene.

We further evaluated these reaction conditions in the selective oxidation of benzylic and allylic alcohols to the corresponding aldehydes by Au NPs supported on metal oxides (only the best results are presented) as shown in Table 2.

Benzylic alcohol 1a was converted with excellent conversion (99\%) and selectivity in $\mathbf{1 b}$ in $87 \%$ isolated yields (entry 1 ). Aliphatic allylic alcohols 2-4a were similarly oxidised with high selectivities, but with lower conversions (68-71\%) and 66-68\% isolated yields (entries 2-4). Cinnamyl alcohol 5a and some derivatives 6-7a with different substitution patterns on the benzenic ring were efficiently converted to cinnamaldehyde $\mathbf{5 b}$ and related products $\mathbf{8 - 7 b}$ with excellent conversions (100\%) and almost quantitative isolated yields (entries 5-7). A sufficient $\mathrm{O}_{2}$ supply was obtained by saturation of the solvent by bubbling before use and running the reaction under $\mathrm{O}_{2}(1 \mathrm{~atm})$.
Table 2. Conversion and selectivity in the oxidation of various alcohols.

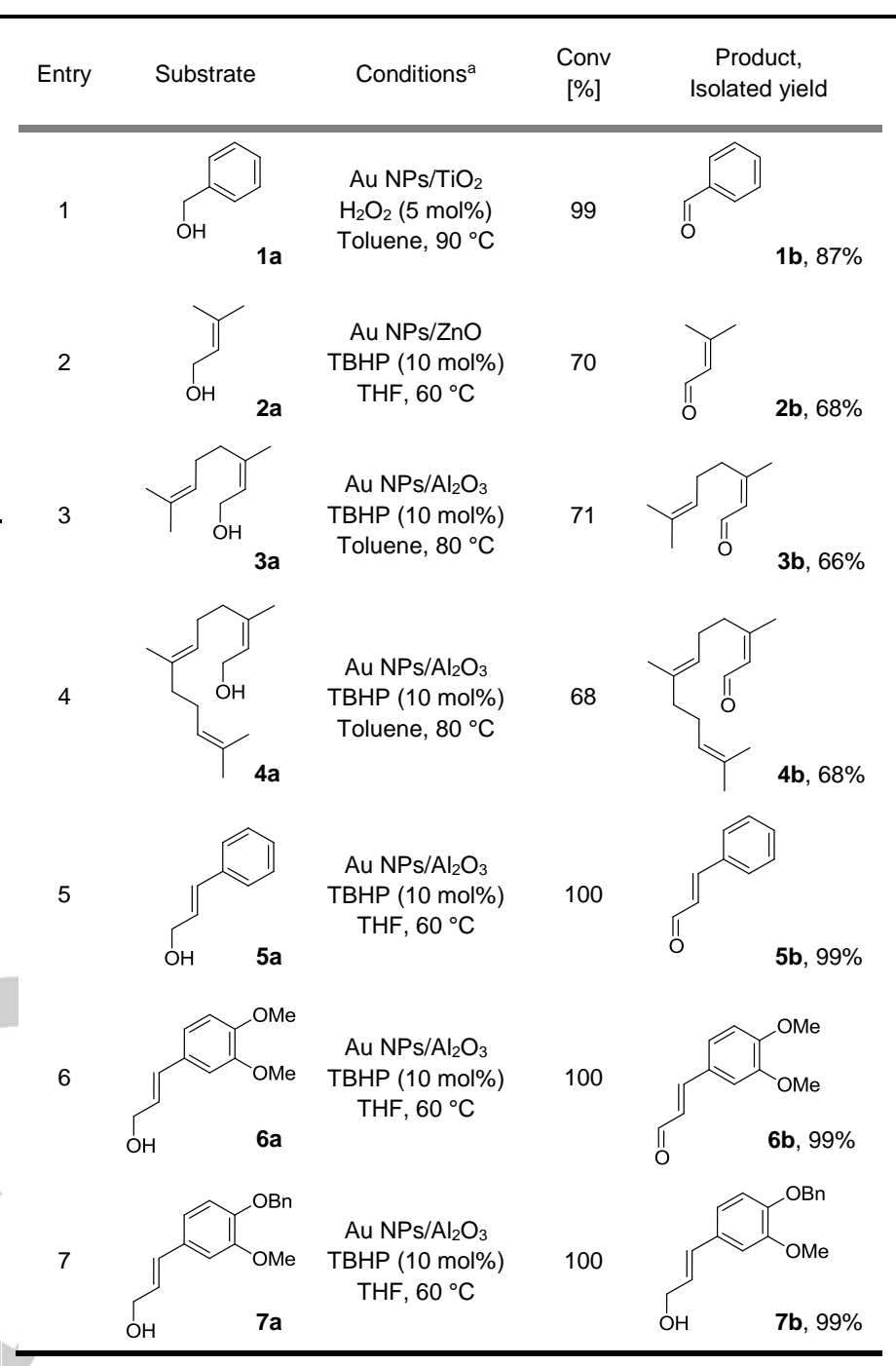

a Catalysts were used in $1 \mathrm{~mol} \%$ catalyst/substrate ratio for reaction times of 16 hrs. Reactions were conducted under an $\mathrm{O}_{2}$ atmosphere (1 atm).

TEM analysis of the Au NPs used revealed average particle sizes of $1.56 \mathrm{~nm}$ for $\mathrm{Au} / \mathrm{TiO}_{2}, 2.63 \mathrm{~nm}$ for $\mathrm{Au} / \mathrm{Al}_{2} \mathrm{O}_{3}$, and $1.54 \mathrm{~nm}$ for $\mathrm{Au} / \mathrm{ZnO}$ with relatively narrow dispersities (Figure 1 and $\mathrm{SI}$ ). In most instances, optimal results were obtained with $\mathrm{Au}$ $\mathrm{NPs} / \mathrm{Al}_{2} \mathrm{O}_{3}$ as catalyst. In previous reports, it was shown that the presence of mineral bases or fluoride ions during the oxidation could be beneficial, ${ }^{[22]}$ but in our conditions, catalytic testing with $\mathrm{K}_{2} \mathrm{CO}_{3}$ and $\mathrm{KF}$ showed no significant effect. An effect of the basic character of the support could not thus be confirmed. More likely, the physical features of the support, i.e. the specific surface area $\left(200-260 \mathrm{~m}_{2} / \mathrm{g}\right.$ for $\mathrm{Al}_{2} \mathrm{O}_{3}, 40-50 \mathrm{~m}_{2} / \mathrm{g}$ for $\mathrm{TiO}_{2}, 40-50$ $\mathrm{m}_{2} / \mathrm{g}$ for $\mathrm{ZnO}$ ) or the internal structure (pores, channels ...) could be of concern herein.

With these promising results in hand for allylic alcohols obtained thanks to a relatively mild and flexible protocol, we could further develop a bicatalytic reaction leading to chromenes by mixing with a second catalytic system. 

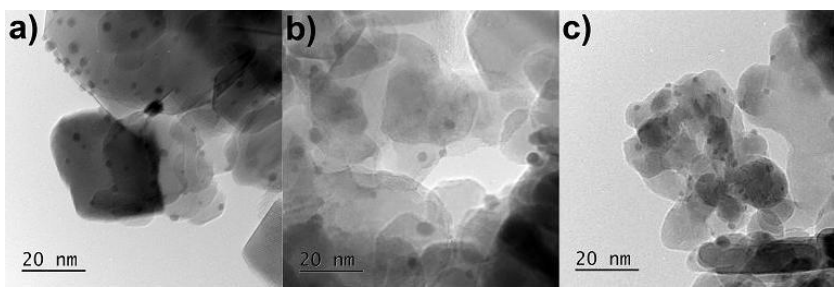

Figure 1. TEM images of $\mathrm{Au}$ NPs supported on $\mathrm{TiO}_{2}(\mathrm{a}), \mathrm{Al}_{2} \mathrm{O}_{3}(\mathrm{~b})$ and $\mathrm{ZnO}$ (c).

Chromenes are motifs occurring in a large number of natural products exhibiting bioactivity. Daurichromene and confluentin have been isolated from Rhododendron dauricum used in traditional Chinese medicine against acute bronchitis ${ }^{[26,}$ 27] Cordiachromene, isolated from ascidians, is a naturally occurring chromene studied for anti-inflammatory and anticancer properties for which multistep synthesis have been proposed. ${ }^{[28]}$ Other chromenes such as eulatachromene, ${ }^{[29]}$ encecalol angelate and encecalol methyl ether, ${ }^{[30]}$ or precocene I and $\|^{[31]}$ have been studied for their diverse biological activities. Chromenes synthesis thus constitutes an important topic of research for which various routes have been described using unsaturated aldehydes as Michael acceptors ${ }^{[27,32,33]}$ or in base catalysed/promoted reactions or involving salicyladehyde as electrophile. ${ }^{[34]}$ Organocatalytic asymmetric versions of the reaction have been reported with prolinol derivatives such as Jorgensen's catalyst. ${ }^{[35]}$ Alternatively, prenylated phenols could also be used as substrates in biomimetic cyclisation ${ }^{[36]}$ or 2-(1hydroxyallyl)phenols in $\mathrm{Fe}(\mathrm{III})$-catalysed allylic cyclisation. ${ }^{[37]}$ Recently, tandem reactions involving a Rh-catalyzed intermolecular hydroacylation of alkynes with salicylaldehydes followed by intramolecular oxo-Michael addition were described for the synthesis of chroman-4-ones. ${ }^{[38]}$

Our plan was to use the $\mathrm{Au} \mathrm{NPs} / \mathrm{O}_{2}$ catalytic system to generate in situ $\alpha, \beta$-unsaturated aldehydes further undergoing a base-catalysed oxa-Michael addition of salicylaldehydes to yield chromenes substituted on positions 2, 3 and 5 in a sequential bicatalytic one-pot/4-steps procedure (Scheme 1). The availability of both unsaturated alcohols and substituted salicylaldehydes ${ }^{[39]}$ granted the applicability of the approach to access various substitution patterns on the resulting chromenes, potentially useful for structure-activity relationship studies and/or synthesis of bioactive compounds. Replacing salicylaldehyde by ortho-aminobenzaldehyde, substituted dihydroquinolines could be similarly obtained efficiently. For substrate $\mathbf{2 a}$, the use of triazabicyclodecene (TBD) as the base at a catalyst ratio of 30 mol\% allowed the formation of chromene $2 \mathrm{c}$ in $64 \%$ yield. For nerol (3a) and $(E, E)$-farnesol (4a), activation with $\mathrm{K}_{2} \mathrm{CO}_{3}(1.1$ equiv., added as a methanolic solution) was sufficient and chromenes 3c and 4c were obtained in 67 and 59\% yields, respectively. With cinnamyl alcohol derivatives $\mathbf{5 a - 7 a}$, the use of pyrrolidine (30 mol\%) in THF in the presence of molecular sieves ( $3 \AA$ ) was necessary for the reaction to proceed efficiently, and the expected chromenes $5 \mathbf{c}-7 \mathbf{c}$ were obtained in $86-93 \%$ yields. By replacing salicylaldehyde with orthoaminobenzaldehyde, dihydroquinolines $\mathbf{5} \mathbf{d}$ and $\mathbf{6 d}$ could be obtained similarly in 93 and $79 \%$ yield, respectively. Variation on the salicylaldehyde partner was also possible with $3 a-5 a$ as the starting alcohols. Salicylaldehydes substituted on the benzene ring with both electron-donating and withdrawing groups could be used and allowed the formation of the corresponding chromenes in $52-79 \%$ isolated yields. It is worth noting that in all these examples, the second step, started upon addition of benzaldehyde derivatives, was performed at room temperature.

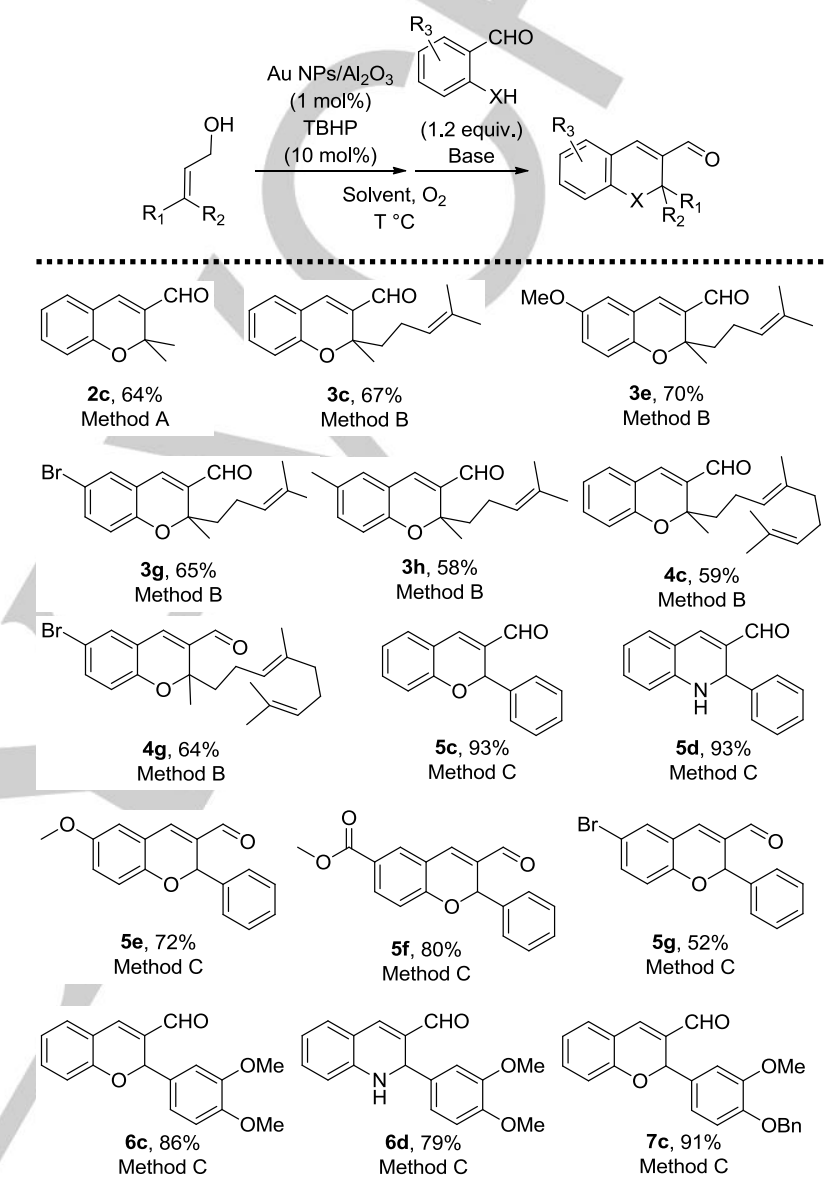

Scheme 1. Bicatalytic one-pot/4-steps synthesis of substituted chromenes/dihydroquinolines from allyl alcohols and aromatic aldehydes. Method A: TBD (30 mol\%), MS $3 \AA$, toluene, $60{ }^{\circ} \mathrm{C}$ then rt; Method $\mathrm{B}: \mathrm{K}_{2} \mathrm{CO}_{3}$ (1.1 equiv. in $\mathrm{MeOH})$, toluene, $80^{\circ} \mathrm{C}$ then rt; Method $\mathrm{C}$ : pyrrolidine $(30 \mathrm{~mol} \%)$, MS $3 \AA$, THF, $60^{\circ} \mathrm{C}$ then rt. See supporting information for details.

Since the preparation of ortho-aminobenzaldehyde was found to be moderately efficient, ${ }^{[40]}$ we reasoned that orthoaminobenzyl alcohol could be used as a substrate too and oxidised in situ. Upon sequential oxidation of cinnamyl alcohol and ortho-aminobenzyl alcohol, dihydroquinoline $\mathbf{5 d}$ was thus obtained in $85 \%$ yield, in an example fitting with the quest for ideal synthesis without purification (Scheme 2). ${ }^{[41]}$

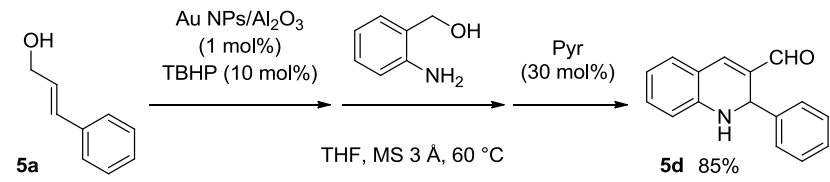

Scheme 2. Synthesis of dihydroquinoline $\mathbf{5 d}$ in one-pot from simple alcohols. 
In terms of reaction mechanism, and taking into account existing literature on the two core reactions taken separately, ${ }^{[22,32]}$ we focused on the possible influence of Au NPs on the heteroMichael/aldolisation process, the base being added after the oxidation process took place.

First of all, when the reaction depicted in Scheme 1 was performed with $\mathbf{3 a}$ in the absence of base, $\mathbf{3 c}$ was obtained in only $5 \%$ yield. In the absence of Au NPs, no oxidation reaction occurred.
With in situ formed Michael acceptors such as citral $\mathbf{3 b}, \mathrm{K}_{2} \mathrm{CO}_{3}$ was offering a sufficient activation, while for substrates such a cinnamaldehyde $\mathbf{5 b}$, the formation of a covalent activated intermediate, i.e. an iminium ion, was necessary for the reaction to proceed through iminium/enamine mechanism. A working mechanism for this bicatalytic process is summarised in Scheme 3.

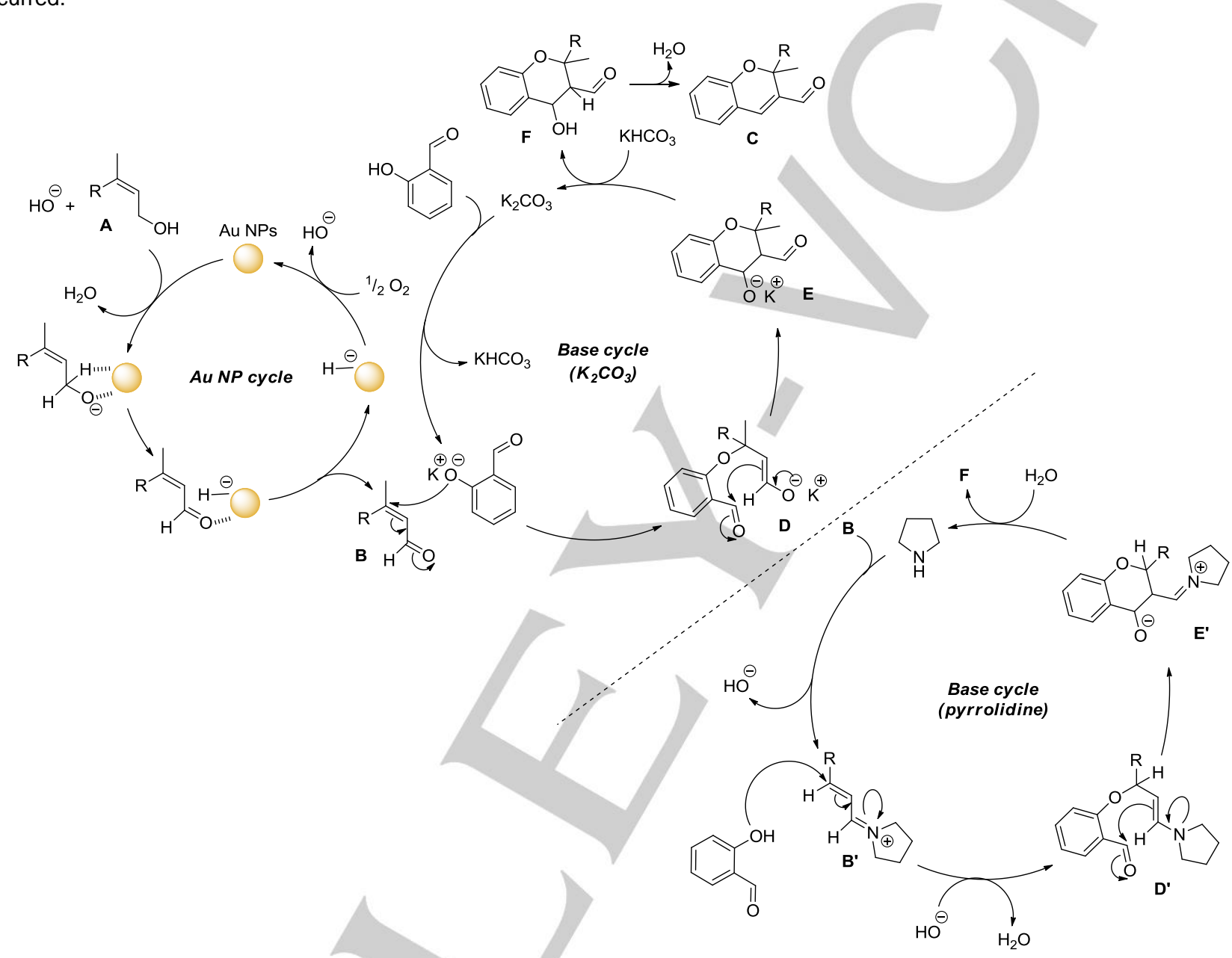

Scheme 3. Working mechanism of the bicatalytic tandem oxidation/hetero-Michael addition/aldolisation/crotonisation reaction

Allylic alcohol A could be first deprotonated to the corresponding alcoholate coordinated to the surface of the NP. A redox process would then take place to yield Michael acceptor B and an Au NP hydride, further re-oxidised by $\mathrm{O}_{2}$ to yield $\mathrm{HO}$. Upon activation by $\mathrm{K}_{2} \mathrm{CO}_{3}$, deprotonated salicylaldehyde would attack intermediate $\mathbf{B}$ to yield potassium enolate $\mathbf{D}$. The latter would cyclise by aldolisation reaction to potassium alcoholate $\mathbf{E}$. Upon re-protonation to $\mathbf{F}$ and dehydration, either thermally-promoted or base-catalysed, chromene $\mathbf{C}$ would be obtained. In the organocatalytic version, i.e. with pyrrolidine, the reaction would proceed through iminium B' and enamine 'D' to form intermediate $\mathbf{E}$ ' hydrolysed to $\mathbf{F}$ with the recovery of the catalyst. In summary, we have developed a step- and atom-economical bicatalytic tandem process allowing a simplified access to biologically relevant chromene and 1,2-dihydroquinoline scaffolds with a large space of substitution possibilities. We have shown that up to five reactions could proceed in the same pot to convert simple starting materials into complex molecules by combining nanocatalysis and base-catalysis. These approaches could be further developed in the future toward an ideal goal of one-pot total synthesis.

\section{Acknowledgements}

This work was supported by the University Nice Sophia Antipolis, the CNRS, and the ANR program CD2I (Nanocausys, grant 12- 
CDII-0010-02). The French MESR is acknowledged for a PhD fellowship to P.D.G. G.J.H., P.J.M. and J.K.E. thank the EPSRC for funding (EP/K014854/1).

Keywords: nanocatalysis - tandem reactions - oxidation • sustainable chemistry $\cdot$ step-economy

[1] a) P. Anastas, J. Warner, Green chemistry: theory and practice, Oxford University Press, Oxford, 1998, 135. b) M. Poliakoff, P. Anastas, Nature 2001, 413, 257. c) R. A. Sheldon, Chem. Commun. 2008, 3352-3365. d) B. M. Trost, Science 1991, 254, 1471-1477.

[2] T. L. Lohr, T. J. Marks, Nat. Chem. 2015, 7, 477-482.

[3] a) X. Li, L. Yang, C. Peng, X. Xie, H.-J. Leng, B. Wang, Z.-W. Tang, G. He, L. Ouyang, W. Huang, B. Han, Chem. Commun. 2013, 49, 8692-8694. b) R.

C. Wende, P. R. Schreiner, Green Chem. 2012, 14, 1821-1849.

[4] a) Y. Jeong, Y. Moon, S. Hong, Org. Lett. 2015, asap. b) L. Li, X.-H. Xia, Y. Wang, P. P. Bora, Q. Kang, Adv. Synth. Catal. 2015, 357, 2089-2097. c) Y. Oonishi, A. Gomez-Suarez, A. R. Martin, Y. Makida, A. M. Z. Slawin, S. P. Nolan, Chem. - Eur. J. 2014, 20, 13507-13510.

[5] C. A. Denard, M. J. Bartlett, Y. Wang, L. Lu, J. F. Hartwig, H. Zhao, ACS Catalysis 2015, 5, 3817-3822.

[6] B. Simmons, A. M. Walji, D. W. C. MacMillan, Angew. Chem. 2009, 121, 4413-4417; Angew. Chem. Int. Ed. 2009, 48, 4349-4353.

[7] a) G. He, F. Wu, W. Huang, R. Zhou, L. Ouyang, B. Han, Adv. Synth. Catal. 2014, 356, 2311-2319. b) C. B. Jacobsen, L. Albrecht, J. Udmark, K. A. Joergensen, Org. Lett. 2012, 14, 5526-5529. c) Y. Liu, M. Nappi, E. C. Escudero-Adan, P. Melchiorre, Org. Lett. 2012, 14, 1310-1313.

[8] D. Hager, D. W. C. MacMillan, J. Am. Chem. Soc. 2014, 136, 16986-16989

[9] a) A. Noble, S. J. McCarver, D. W. C. MacMillan, J. Am. Chem. Soc. 2015, 137, 624-627. b) C. Vila, ChemCatChem 2015, 7, 1790-1793. c) L. Chu, J. M. Lipshultz, D. W. C. MacMillan, Angew. Chem. 2015, 127, 8040-8044; Angew. Chem. Int. Ed. 2015, 54, 7929-7933.

[10] K. Akagawa, S. Takigawa, E. Mano, K. Kudo, Tetrahedron Lett. 2011, 52, 770-773.

[11] N. Nelson, U. Chaudhary, K. Kandel, I. Slowing, Top. Catal. 2014, 57, 1000-1006.

[12] B. Sarmah, R. Srivastava, P. Manjunathan, G. V. Shanbhag, ACS Sustain Chem. Eng. 2015, 3, 2933-2943.

[13] P. K. Sahoo, A. Bose, P. Mal, Eur. J. Org. Chem. 2015, 2015, 6994-6998.

[14] T. Yatabe, X. Jin, K. Yamaguchi, N. Mizuno, Angew. Chem. 2015, 127, 13500-13504; Angew. Chem. Int. Ed. 2015, 54, 13302-13306.

[15] X. Fang, R. Jackstell, A. Börner, M. Beller, Chem. Eur. J. 2014, 20 , $15692-15696$.

[16] a) K. A. Ostrowski, T. A. Faßbach, A. J. Vorholt, Adv. Synth. Catal. 2015, 357, 1374-1380. b) K. A. Ostrowski, T. A. Faßbach, D. Vogelsang, A. J. Vorholt, ChemCatChem 2015, 7, 2607-2613. c) K. Dong, R. Sang, J.-F. Soule, C. Bruneau, R. Franke, R. Jackstell, M. Beller, Chem. Eur. J. 2015, 21, 18033-18037.

[17] L. M. Ambrosini, T. A. Cernak, T. H. Lambert, Tetrahedron 2010, 66, 4882-4887.

[18] G. L. Brett, P. J. Miedziak, Q. He, D. W. Knight, J. K. Edwards, S. H. Taylor, C. J. Kiely, G. J. Hutchings, ChemSusChem 2013, 6, 1952-1958.

[19] a) L. L. Chng, J. Yang, J. Y. Ying, ChemSusChem 2015, 8, 1916-1925. b) H. Miyamura, H. Min, J.-F. Soulé, S. Kobayashi, Angew. Chem. Int. Ed. 2015, 54, 7564-7567. c) J.-F. Soulé, H. Miyamura, S. Kobayashi, Chem.
Asian. J. 2013, 8, 2614-2626. d) G. T. Whiting, S. A. Kondrat, C. Hammond, N. Dimitratos, Q. He, D. J. Morgan, N. F. Dummer, J. K. Bartley, C. J. Kiely, S. H. Taylor, G. J. Hutchings, ACS Catalysis 2015, 5, 637-644.

[20] W.-J. Yoo, H. Miyamura, S. Kobayashi, J. Am. Chem. Soc. 2011, 133, 3095-3103.

[21] A. S. K. Hashmi, G. J. Hutchings, Angew. Chem. 2006, 118, 8064-8105; Angew. Chem. Int. Ed. 2006, 45, 7896-7936.

[22] E. Skupien, R. Berger, V. Santos, J. Gascon, M. Makkee, M. Kreutzer, P. Kooyman, J. Moulijn, F. Kapteijn, Catalysts 2014, 4, 89-115.

[23] H. Zou, R. Wang, J. Dai, Y. Wang, X. Wang, Z. Zhang, S. Qiu, Chem. Commun. 2015, 51, 14601-14604.

[24] D. I. Enache, J. K. Edwards, P. Landon, B. Solsona-Espriu, A. F. Carley, A. A. Herzing, M. Watanabe, C. J. Kiely, D. W. Knight, G. J. Hutchings, Science 2006, 311, 362-365.

[25] a) N. Dimitratos, J. A. Lopez-Sanchez, J. M. Anthonykutty, G. Brett, A. F. Carley, R. C. Tiruvalam, A. A. Herzing, C. J. Kiely, D. W. Knight, G. J. Hutchings, Phys. Chem. Chem. Phys. 2009, 11, 4952-4961. b) J. K. Edwards, B. E. Solsona, P. Landon, A. F. Carley, A. Herzing, C. J. Kiely, G. J. Hutchings, J. Catal. 2005, 236, 69-79.

[26] a) B. Lesch, J. Toröng, M. Nieger, S. Bräse, Synthesis 2005, 2005, 18881900. b) N. Iwata, N. Wang, X. Yao, S. Kitanaka, J. Nat. Prod. 2004, 67, 1106-1109.

[27] Y. R. Lee, J. H. Choi, S. H. Yoon, Tetrahedron Lett. 2005, 46, 7539-7543.

[28] a) M. Menna, A. Aiello, F. D'Aniello, C. Imperatore, P. Luciano, R. Vitalone, C. Irace, R. Santamaria, Eur. J. Org. Chem. 2013, 2013, 3241-3246. b) Y. Noda, M. Yasuda, Helv. Chim. Acta 2012, 95, 1946-1952.

[29] J. H. Kim, N. Mahoney, K. L. Chan, R. J. Molyneux, B. C. Campbell, Cur. Microbiol. 2004, 49, 282-287.

[30] D. Harel, S. A. Khalid, M. Kaiser, R. Brun, B. Wünsch, T. J. Schmidt, J. Ethnopharmacol. 2011, 137, 620-625.

[31] M. Szczepanik, R. Obara, A. Szumny, B. Gabryś, A. Halarewicz-Pacan, J. Nawrot, C. Wawrzeńczyk, J. Agric. Food Chem. 2005, 53, 5905-5910.

[32] D. Lanari, O. Rosati, M. Curini, Tetrahedron Lett. 2014, 55, 1752-1755.

[33] M. C. Bröhmer, N. Volz, S. Bräse, Synlett 2009, 2009, 1383-1386.

[34] B. Sarmah, G. Baishya, N. Hazarika, P. J. Das, Synlett 2014, 26, 21512155.

[35] a) T. Govender, L. Hojabri, F. M. Moghaddam, P. I. Arvidsson, Tetrahedron-Asymmetr. 2006, 17, 1763-1767. b) K. Liu, X. Jiang, Eur. J. Org. Chem. 2015, 2015, 6423-6428. c) H. Sundén, I. Ibrahem, G.-L. Zhao, L. Eriksson, A. Córdova, Chem. Eur. J. 2007, 13, 574-581.

[36] a) K. Takenaka, Y. Tanigaki, M. L. Patil, C. V. L. Rao, S. Takizawa, T. Suzuki, H. Sasai, Tetrahedron-Asymmetr. 2010, 21, 767-770. b) M. Bobin, I. J. Day, S. M. Roe, E. M. E. Viseux, Dalton Trans. 2013, 42, 6592-6602.

[37] L. Calmus, A. Corbu, J. Cossy, Adv. Synth. Catal. 2015, 357, 1381-1386.

[38] X.-W. Du, L. M. Stanley, Org. Lett. 2015, 17, 3276-3279.

[39] D. Reinhard, L. Schöttner, V. Brosius, F. Rominger, M. Mastalerz, Eur. J. Org. Chem. 2015, 2015, 3274-3285.

[40] PCC: 0\%; TEMPO/Cu: 20\%; AUROlite/O 2 : 25\% isolated yield of orthoaminobenzaldehyde

[41] S. Balieu, G. E. Hallett, M. Burns, T. Bootwicha, J. Studley, V. K. Aggarwal, J. Am. Chem. Soc. 2015, 137, 4398-4403. 
Entry for the Table of Contents (Please choose one layout)

Layout 2:

\section{COMMUNICATION}

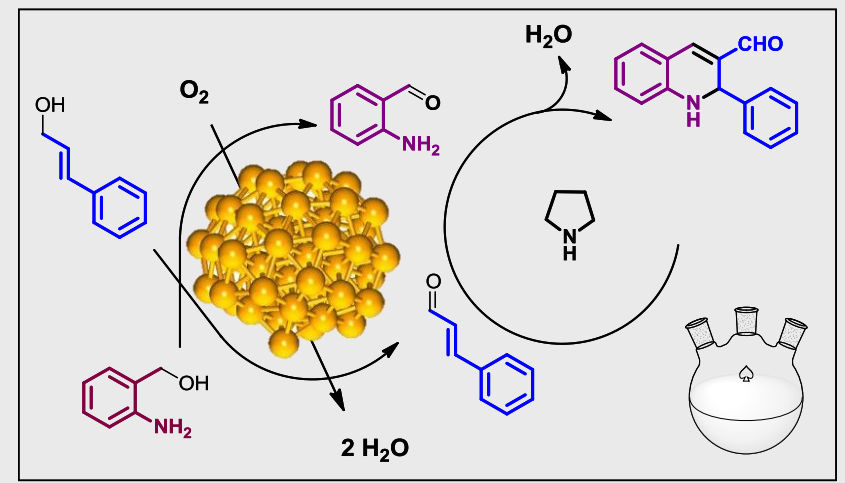

Pascal D. Giorgi, Peter J. Miedziak, Jennifer K. Edwards, Graham J. Hutchings, and Sylvain Antoniotti*

Page No. - Page No.

Bicatalytic multistep reactions en route to the one-pot total synthesis of complex molecules: easy access to chromene and 1,2-dihydroquinoline derivatives from simple substrates 